\title{
Further Studies on Aggregation and Insolubilization of Soybean 11S Globulin with Humidity during Storage
}

\author{
Yuji Hoshi and Fumio Yamauchi \\ Department of Food Chemistry, Faculty of Agriculture, \\ Tohoku University, Sendai 980, Japan
}

Received October 13, 1982

\begin{abstract}
When soybean lyophilized $11 \mathrm{~S}$ globulin was stored at $\mathrm{RH} 96 \%$ and $50^{\circ} \mathrm{C}$, the redispersibility of the protein as measured over a $1 \mathrm{hr}$ period drastically decreased after $4 \mathrm{hr}$. When the redispersing time was prolonged to $24 \mathrm{hr}, 11 \mathrm{~S}$ globulins stored for up to $12 \mathrm{hr}$ redispersed similarly to the control, but became insoluble after $24 \mathrm{hr}$ of storage. A gel filtration study showed that the stored 11S globulin had already polymerized mainly through disulfide bonds after $12 \mathrm{hr}$ of storage.

Scanning electron microscopic observation showed that a globular structure of the control $11 \mathrm{~S}$ globulin changed to an aggregated structure during storage. Polymerized subunits linked with disulfide bridges were observed using gel filtration in a sodium dodecyl sulfate (SDS) solution and SDS polyacrylamide gel electrophoresis and the number of the polymerized subunits increased during storage. The $11 \mathrm{~S}$ globulin, however, did not polymerize with humidity as much as in heat denaturation at $100^{\circ} \mathrm{C}$ (ionic strength 0.5 , protein concentration $0.5 \%$ ).
\end{abstract}

Many studies on the storage of soybeans have recently been reported. ${ }^{1 \sim 13)}$ Okamoto et $a l .^{7)}$ and Saio et $a .^{2,3)}$ have reported that relative humidity seems to be important for the deterioration of soybean during storage. We have made studies from the standpoint that soybean protein isolates will be increasingly utilized as processing materials for foods and that it is necessary to obtain basic data on the changes of soybean proteins during storage. ${ }^{14 \sim 16)}$

Soybean proteins consist of 7S globulin (beta-conglycinin) and 11S globulin (glycinin) as their major components. ${ }^{17)} \mathrm{We}$ have reported the effect of relative humidity $(\mathrm{RH})$ on soybean $7 \mathrm{~S}$ and $11 \mathrm{~S}$ globulins ${ }^{14)}$ and acid precipitated protein, ${ }^{15)}$ which consists of $7 \mathrm{~S}$ and $11 \mathrm{~S}$ globulins, and on the role of disulfide bonds in the polymerization of $7 \mathrm{~S}$ globulin during storage. ${ }^{16)}$ This paper describes the aggregation and insolubilization of $11 \mathrm{~S}$ globulin in more detail.

\section{MATERIALS AND METHODS}

Preparation of $11 S$ globulin. Soybeans (var. Raiden,
1981 crop.) were defatted with $n$-hexane at room temperature. A crude 11S globulin fraction was prepared from defatted soybean meals according to the method of Thanh and Shibasaki ${ }^{18)}$ and purified by ammonium sulfate fractionation. ${ }^{18)}$ The protein was lyophilized and stored in a desiccator at $5^{\circ} \mathrm{C}$.

Humidity condition of $11 S$ globulin. The lyophilized $11 \mathrm{~S}$ globulin was placed in a desiccator containing a saturated $\mathrm{K}_{2} \mathrm{SO}_{4}$ solution at $50^{\circ} \mathrm{C}$, which gave an $\mathrm{RH}$ level of $96 \%$.

Determination of protein redispersibility. When the redispersibility was examined in a phosphate buffer $\left(0.0026 \mathrm{M} \mathrm{KH}_{2} \mathrm{PO}_{4}, 0.0325 \mathrm{M} \mathrm{K}_{2} \mathrm{HPO}_{4}\right.$ and $0.4 \mathrm{M} \mathrm{NaCl}$, $\mathrm{pH}$ 7.6), the buiret method was used as described previously. ${ }^{14)}$ To examine the redispersibility in a $0.5 \%$ SDS solution, the following method was used: Three $\mathrm{ml}$ of the $0.5 \%$ SDS solution was added to about $30 \mathrm{mg}$ of $11 \mathrm{~S}$ globulin. The mixture was stirred for $1 \mathrm{hr}$ or stood for $24 \mathrm{hrs}$ at room temperature and submitted to centrifugation $\left(25,400 \times g, 20^{\circ} \mathrm{C}, 15 \mathrm{~min}\right)$. The supernatant was filled up to $50 \mathrm{ml}$ and the absorbance was measured at $280 \mathrm{~nm}$.

Scanning electron microscopy. Scanning electron microscopic observation was carried out with a Hitachi S-700. The 11S globulin stored for 3 days was kept in distilled water for $24 \mathrm{hr}$, then frozen and lyophilized. The dried protein samples were mounted on an alminum stab and coated with gold. The specimens were observ- 
ed at an accelerating voltage of $20 \mathrm{kV}$.

SDS polyacrylamide gel electrophoresis (SDS-PAGE). SDS polyacrylamide gel electrophoresis was carried out using a slab gel apparatus according to Swank et al. ${ }^{20)}$ All gels were stained with Coomassie Blue and destained by diffusion in $7.5 \% \mathrm{CH}_{3} \mathrm{OH}-5 \% \mathrm{CH}_{3} \mathrm{COOH}$-water. The destained gels were scanned at $570 \mathrm{~nm}$ (reference $720 \mathrm{~nm}$ ) with a Shimadzu CS-900 Dual-Wavelength TLC Scanner.

\section{RESULTS}

\section{Changes in redispersibility during storage}

Figure 1 shows the changes in redispersibility of the lyophilized $11 \mathrm{~S}$ globulin stored at RH $96 \%$ and $50^{\circ} \mathrm{C}$. When the redispersing time was set at $1 \mathrm{hr}$, the redispersibility lowered to $19 \%$ after $4 \mathrm{hr}$ and the $11 \mathrm{~S}$ globulin became completely insoluble beyond $24 \mathrm{hr}$ of storage. On the other hand, when the redispersing time was prolonged to $24 \mathrm{hr}$, no marked decrease in redispersibility was observed up to $12 \mathrm{hr}$ of storage. The 11S globulin, however, became almost insoluble after $24 \mathrm{hr}$ of storage.

Seven S globulin, which is another component of soybean proteins, did not show an increase in redispersibility as with $11 \mathrm{~S}$ globulin when the redispersing time was prolonged (redispersibility data not shown). The state of dispersion of $11 \mathrm{~S}$ and $7 \mathrm{~S}$ globulins is shown in Figs. 2 and 3, respectively. The $11 \mathrm{~S}$ globulin

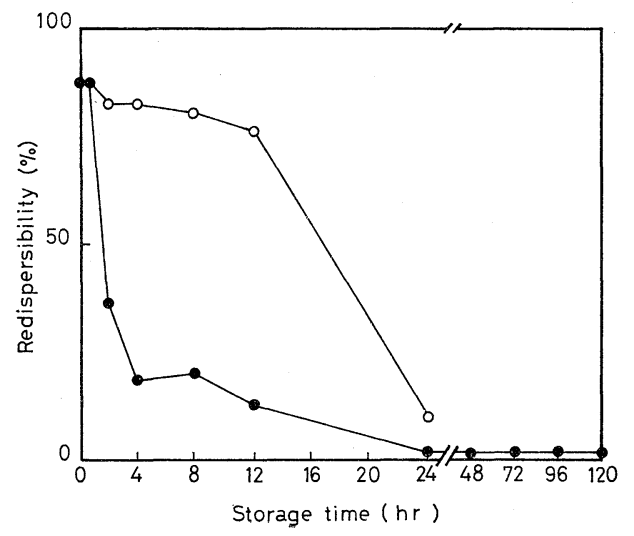

FIG. 1. Changes in Redispersibility of Stored 11S Globulin in the Phosphate Buffer.

One hour redispersing time (•) and $24 \mathrm{hr}$ redispersing time $(\mathrm{O})$.

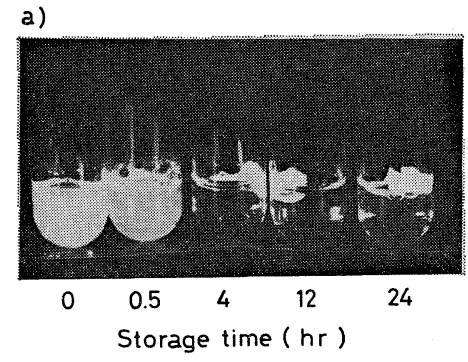

b)

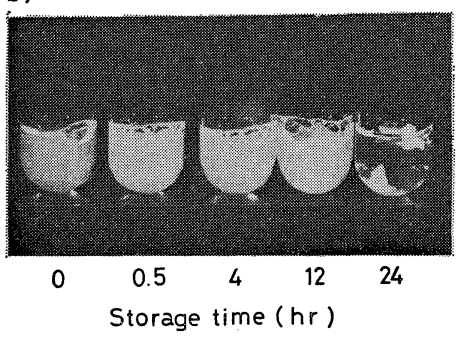

FIG. 2. Photographs of $11 \mathrm{~S}$ Globulin Redispersed after Storage in the Phosphate Buffer.

Photographs were taken before centrifugation. One hour redispersing time, a); $24 \mathrm{hr}$ redispersing time, b).

a)

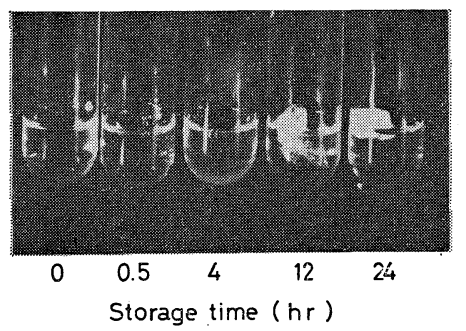

b)

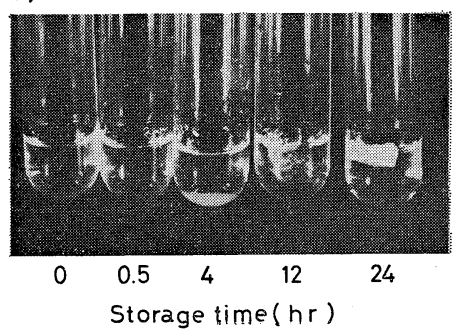

FIG. 3. Photographs of 7S Globulin Redispersed after Storage in the Phosphate Buffer.

Photographs were taken before centrifugation. One hour redispersing time, a); $24 \mathrm{hr}$ redispersing time, b).

stored beyond $4 \mathrm{hr}$ formed particles and remained floating in the buffer over a $1 \mathrm{hr}$ redispersing time (Fig. 2a). On the other hand, $11 \mathrm{~S}$ globulins stored for up to $12 \mathrm{hr}$ dispersed 
in a $24 \mathrm{hr}$ redispersing time (Fig. 2b). The $11 \mathrm{~S}$ globulin stored for $24 \mathrm{hr}$ did not disperse and showed a gel-like state. Furthermore, 11S globulins stored for 2 to 5 days showed a similar gel-like state to that of the 1 day stored $11 \mathrm{~S}$ globulin (data not shown).

In the case of $7 \mathrm{~S}$ globulin (Fig. 3b), the unstored sample had little turbidity, while minor precipitation occurred during $4 \mathrm{hr}$ of storage. Furthermore, the particles of lyophilized $7 \mathrm{~S}$ globulins remained floating in the buffer beyond $12 \mathrm{hr}$ of storage. Prolonging the redispersing time to $24 \mathrm{hr}$ had little effect on the redispersal behavior (Fig. 3b).

\section{Gel filtration with Sepharose $4 B$}

After the $12 \mathrm{hr}$ stored $11 \mathrm{~S}$ globulin was redispersed in the phosphate buffer for $24 \mathrm{hr}$, the mixture was submitted to centrifugation $\left.25,400 \times g, 20^{\circ} \mathrm{C}, 15 \mathrm{~min}\right)$. The supernatant was applied on a column of Sepharose 4B. The results are shown in Fig. 4. The main peak around fraction No. 42 corresponds to the $11 \mathrm{~S}$ globulin. Fraction Nos. $21 \sim 23$ are the void volume, in which the cause of turbidity of the $11 \mathrm{~S}$ globulin solution was eluted. In the $11 \mathrm{~S}$ globulin stored for $12 \mathrm{hr}$, the materials eluted in void volume fraction increased. Furthermore, the presence of polymers having various particle weights was observed in fraction Nos. $24 \sim 40$. The polymers were sup-

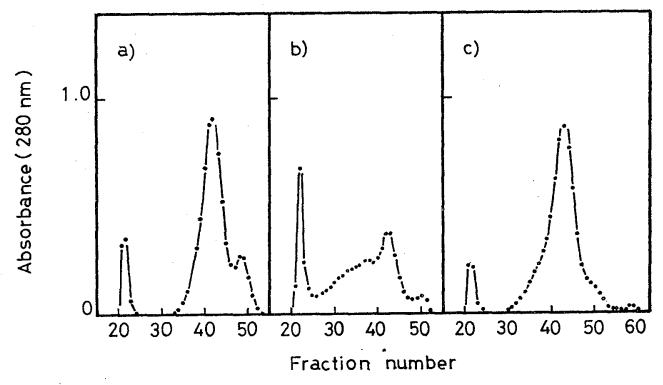

Fig. 4. Sepharose 4B Chromatography of Stored 11S Globulin.

A column of Sepharose 4B $(1.7 \times 90 \mathrm{~cm})$ was eluted with the phosphate buffer ( $\mathrm{pH} 7.6$ ionic strength 0.5$)$ in $3 \mathrm{ml}$ fractions.

Control, a); $12 \mathrm{hr}$ stored, b); $12 \mathrm{hr}$ stored $11 \mathrm{~S}$ globulin followed by dialysis against the phosphate buffer containing $0.01 \mathrm{M}$ 2-mercaptoethanol, c). posed to have approx. particle weights of $7 \times$ $10^{5} \sim 10^{7}$ daltons and the species in the void volume had approx. particle weights more than $2 \times 10^{7}$ daltons using various standard proteins. Although the redispersibility did not change, it was observed that the $11 \mathrm{~S}$ globulin had already polymerized during storage. Figure $4 \mathrm{c}$ shows the elution pattern of the $12 \mathrm{hr}$-stored $11 \mathrm{~S}$ globulin which was dialyzed against a phosphate buffer containing $0.01 \mathrm{M} 2$-mercaptoethanol overnight at $5^{\circ} \mathrm{C}$ after it had been redispersed in the phosphate buffer for $24 \mathrm{hr}$. As shown in Fig. 4c, most of the polymers in Fig. $4 \mathrm{~b}$ disappeared and the elution pattern was similar to that of the control, although a little polymer existed in fraction Nos. $30 \sim 35$. It seems that disulfide bonds were related to the polymerization of stored $11 \mathrm{~S}$ globulin with humidity.

\section{Scanning electron microscopy (SEM)}

Figure 5 shows the SEM micrographs of both the control and stored $11 \mathrm{~S}$ globulins. The control 11S globulin had a globular micro structure. On the other hand, the stored $11 \mathrm{~S}$ globulin had a highly aggregated structure.

\section{Effects of SDS on redispersibility}

It has been reported in the previous paper ${ }^{14)}$ that 2-mercaptoethanol had much effect on restoration of the redispersibility of the stored $11 \mathrm{~S}$ globulin and SDS was not effective. The time course for redispersibility of the stored $11 \mathrm{~S}$ globulin in an SDS solution was examined. a)

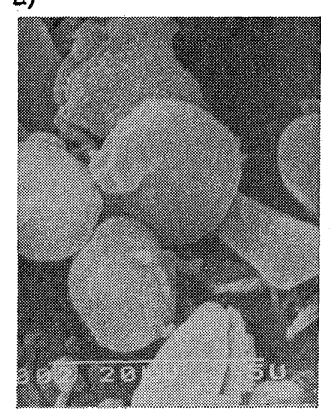

b)

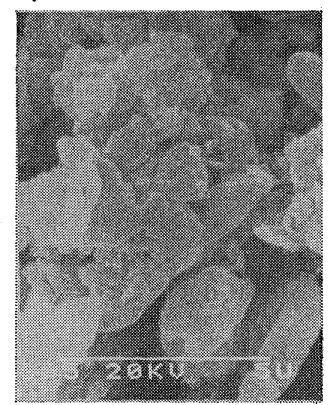

FIG. 5. Scanning Electron Microscopic Observation of 11 S Globulin.

Control, a); 3 day-stored, b). 


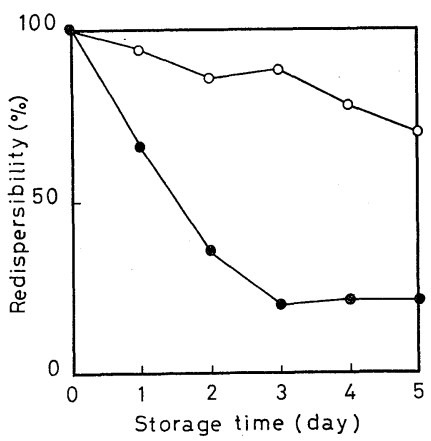

FIG. 6. Changes in Redispersibility of Stored $11 \mathrm{~S}$ Globulin in $0.5 \%$ SDS solution.

One hour redispersing time $(\bullet)$ and $24 \mathrm{hr}$ redispersing time $(\bigcirc)$.

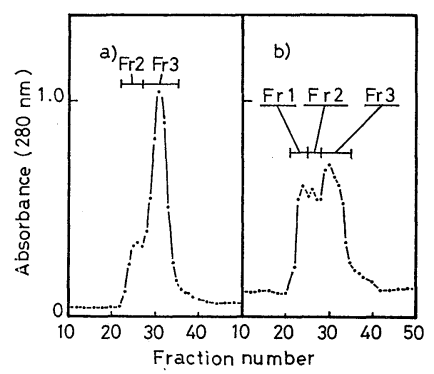

FIG. 7. Gel Filtration Patterns of $11 \mathrm{~S}$ Globulin Stored for 2 Days on Sephacryl S-300 in 0.5\% SDS solution.

A column of Sephacryl S-300 $(1.7 \times 90 \mathrm{~cm})$ was eluted with a $0.5 \%$ SDS solution in $3 \mathrm{ml}$ fractions. After dissolving the stored $11 \mathrm{~S}$ globulin for $24 \mathrm{hr}$, the mixture was submitted to centrifugation $\left(25,400 \times g, 20^{\circ} \mathrm{C}\right.$, $15 \mathrm{~min}$ ) and the supernatant was applied on the column.

Control, a); 2 day-stored, b).

The results are shown in Fig. 6. In the case of a $1 \mathrm{hr}$ redispersing time, the redispersibility began to decrease markedly after 1 day and became constant beyond 3 days (about $21 \%$ ) as reported in the previous paper. ${ }^{14)}$ On the other hand, a slow decrease in redispersibility was observed in the case of a $24 \mathrm{hr}$ redispersing time. The redispersibility was about $70 \%$ after 5 days.

\section{Gel filtration with Sephacryl S-300}

Since redispersibility in a $0.5 \%$ SDS solution decreased with time and the presence of polymerized subunits of $11 \mathrm{~S}$ globulin linked with disulfide bonds was expected, fractiona- tion of the stored $11 \mathrm{~S}$ globulin was carried out with Sephacryl S-300 in a $0.5 \%$ SDS solution. The gel filtration patterns of Sephacryl S-300 are shown in Fig. 7. In the control 11S globulin, Fr. 2 with higher molecular weights was observed, as well as Fr. 3 as a major peak. When the 11S globulin was stored for 2 days, Fr. 1 newly appeared and the quantity in Fr. 3 decreased.

\section{SDS-polyacrylamide gel electrophoresis}

The species in each fraction from the gel filtration with Sephacryl S-300 were examined with SDS-PAGE. The results are shown in Fig. 8. In Fr. 1, polymers (b-1) which could not penetrate into the gel existed as main components besides b-2. Fr. 2 gave mainly b- 2 and b-3 components, and intermediary subunits of $11 \mathrm{~S}$ globulin (IS) were contained in Fr. 3. When their molecular weights were determined using standard proteins, $b-1$ had more than $20 \times 10^{4}, b-213 \times 10^{4}, b-3.11 .2 \times 10^{4}$ and the IS $6.4 \times 10^{4}$, respectively. When 2 -mercapto-

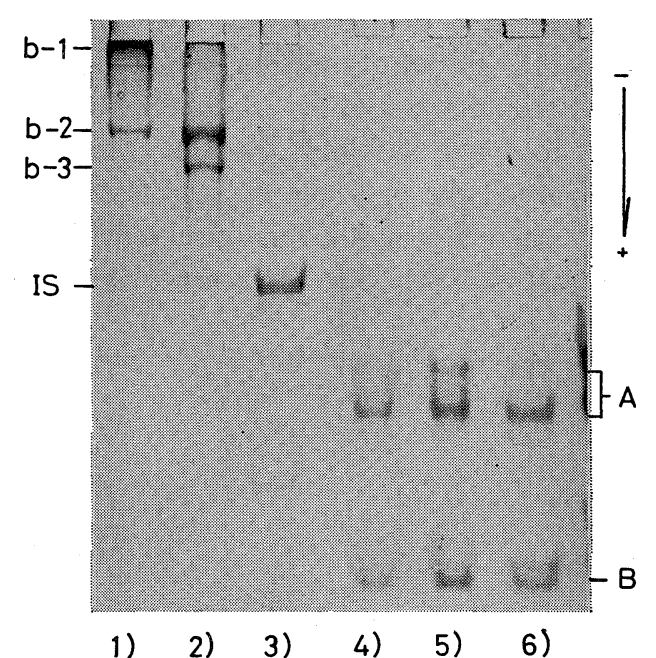

FIG. 8. SDS Polyacrylamide Gel Electrophoretic Patterns for Each Fraction of Fig. 7b.

SDS polyacrylamide gel electrophoresis was carried out in $8 \%$ gels.

Fr 1, 1); Fr 2, 2); Fr 3, 3), in the absence of 2-mercaptoethanol (2-ME).

Fr 1, 4); Fr 2, 5); Fr 3, 6), in the presence of 2-ME. IS is the intermediary subunits of $11 \mathrm{~S}$ globulin. $\mathrm{A}$ and $\mathrm{B}$ are the acidic and basic subunits of $11 \mathrm{~S}$ globulin. b-1, b-2 and b-3 are shown in the text. 


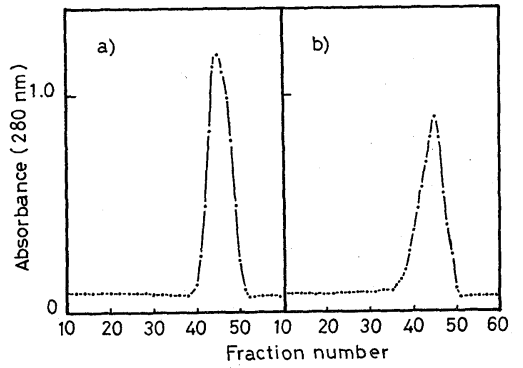

FIG. 9. Gel Filtration Patterns of 11S Globulin Stored for 2 Days on Toyo Pearl HW-75 in $0.5 \%$ SDS Solution.

A column of HW-75 $(1.7 \times 90 \mathrm{~cm})$ was eluted with a $0.5 \%$ SDS solution in $3 \mathrm{ml}$ fractions. Control, a); 2-day stored, b).

ethanol was added to each fraction, the acidic and basic subunits, which are the constituent subunits of $11 \mathrm{~S}$ globulin, appeared.

\section{Gel filtration with Toyo Pearl HW-75}

The 2 day-stored $11 \mathrm{~S}$ globulin was redispersed in a $0.5 \%$ SDS solution for $24 \mathrm{hr}$ and the mixture was submitted to centrifugation $\left(25,400 \times g, 20^{\circ} \mathrm{C}, 15 \mathrm{~min}\right)$. The supernatant was applied on a column of Toyo Pearl HW-75 and the results are shown in Fig. 9. In both the control and the 11S globulin stored for 2 days a single peak eluted in fraction Nos. $40 \sim 50$, although the peak eluted from the fraction No. 36 in the latter.

\section{Changes in the relative amount of polymerized subunits during storage}

Changes in the amount of the polymerized subunits mentioned in Fig. 8 during storage were examined. Stored $11 \mathrm{~S}$ globulins were kept in a $0.5 \%$ SDS solution for $24 \mathrm{hr}$ and the mixture was submitted to centrifugation $\left(25,400 \times g, 20^{\circ} \mathrm{C}, 15 \mathrm{~min}\right)$. The supernatant was subjected to SDS-PAGE and the relative amounts of the polymer fractions (b-1, b-2 and $b-3$ ) and IS were estimated densitometrically. The results are shown in Fig. 10. In the control $11 \mathrm{~S}$ globulin, the IS was about $88 \%$ and the total polymer fraction (polymerized subunits) was about $12 \%$. These total polymer fractions increased with storage time up to 1

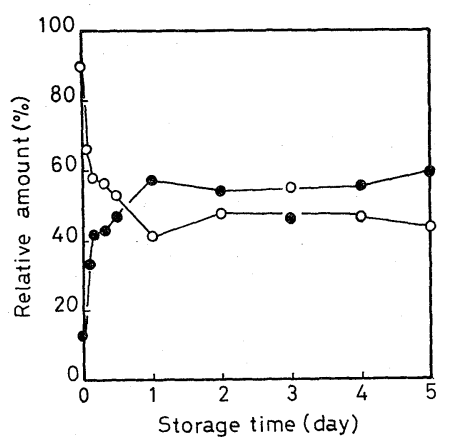

Fig. 10. Changes in Relative Amounts of the Polymerized Subunits and Intermediary Subunits during Storage.

The amount of IS $(O)$ and the amount of the polymerized subunits $(\bullet)$ which is the total of b-1, b-2 and b-3.

day (about 60\%) and became constant beyond 2 days.

\section{DISCUSSION}

When soybean $11 \mathrm{~S}$ globulin was stored at RH $96 \%$ and $50{ }^{\circ} \mathrm{C}$, redispersibility in the phossphate buffer decreased. Although the stored $11 \mathrm{~S}$ globulin did not completely redisperse and remained floating in the buffer in the case of a $1 \mathrm{hr}$ redispersing time, the $11 \mathrm{~S}$ globulins stored for up to $12 \mathrm{hr}$ redispersed similarly to the control $11 \mathrm{~S}$ globulin when the redispersing time was prolonged to $24 \mathrm{hr}$. It was, however, observed from gel filtration with Sepharose $4 \mathrm{~B}$ that $11 \mathrm{~S}$ globulin stored for $12 \mathrm{hr}$ had already polymerized in spite of its high redispersibility. When the $12 \mathrm{hr}$-stored $11 \mathrm{~S}$ globulin was redispersed in the phosphate buffer for $24 \mathrm{hr}$ and the solution was dialyzed against a phosphate buffer containing $0.01 \mathrm{M}$ 2-mercaptoethanol, most of the polymeric species in Fig. 4b disappeared as shown in Fig. 4c. It seems that disulfide bonds were related to the polymerization of $11 \mathrm{~S}$ globulin with humidity. On the other hand, prolonging the redispersing time to $24 \mathrm{hr}$ had little effect on the redispersing behavior of stored $7 \mathrm{~S}$ globulin.

When the 11S globulins stored for more than 1 day were kept in the buffer for $24 \mathrm{hr}$, the 
insoluble masses presented gels. From the scanning electron microscopic observation, although the control 11S globulin had a globular structure, this structure collapsed and the $11 \mathrm{~S}$ globulin formed an aggregated structure during storage. Scanning electron micoscopic observation of soy protein isolates have shown that they posses globular structures as well. ${ }^{21}$ ) Although the stored 11S globulin had an aggregated structure, it did not have a three dimensional network structure like tofu gels. This may be the cause of the massy gels of the stored 11S globulins. The lyophilized 11S globulin formed such an aggregated structure as to be redispersed with the phosphate buffer in a $24 \mathrm{hr}$ redispersing time after up to $12 \mathrm{hr}$ of storage. Prolonging the storage time, however, made the $11 \mathrm{~S}$ globulin form a stronger aggregated structure which could not be redispersed with the buffer and could be solubilized with a $0.5 \%$ SDS solution in $24 \mathrm{hr}$ but not in $1 \mathrm{hr}$.

When the stored 11S globulin was submitted to SDS-PAGE in the absence of 2-mercaptoethanol, b-1, b-2, b-3 and IS appeared. Each band was composed of equal moles of the acidic and basic subunits. Eleven S globulin consists of two monomers; each monomer contains three intermediary subunits (IS-1, MW= $5.8 \times 10^{4} ; \quad$ IS-2, $\quad \mathrm{MW}=6.0 \times 10^{4}$ and IS-3, $\mathrm{MW}=6.3 \times 10^{4}$ ) consisting of one mole of the acidic subunit and one mole of the basic subunit linked with disulfide bridges. ${ }^{22)}$ These intermediary subunits appeared as one band in the SDS-PAGE used in this experiment. Although bands $b-2$ and $b-3$ are supposed to be dimers of these IS's, this is not yet clear.

Although the stored 11S globulin was fractionated into three fractions with gel filtration of Sephacryl S-300, only one peak existed in Toyo Pearl HW-75 chromatography. Yamagishi et al. have reported the heat denaturation of $11 \mathrm{~S}$ globulin $^{23)}$; when $11 \mathrm{~S}$ globulin is heated at $100^{\circ} \mathrm{C}-0.5$ ionic strength $-0.5 \%$ protein concentration, the precipitate is formed and gel filtration of the precipitate with Sepharose CL-2B in a $0.5 \%$ SDS solution gives two peaks. The first peak contains aggregates of highly polymerized subunits, and the second peak contains a monomer of the basic subunit and seven kinds of oligomers, with various proportions of the basic subunits to the acidic subunit. In our study, gel filtration with Toyo Pearl HW-75 gave one peak. It is considered that the subunits of $11 \mathrm{~S}$ globulin did not polymerize as much as they did in heat denaturation with disulfide bridges. The number of polymerized subunits increased during storage. It seems that disulfide bridges were mainly formed between 11S globulin molecules. Consequently, 11S globulin seems to polymerize (Fig. 4c), then, aggregate and finally become insoluble during storage with humidity. SDS probably cleaved bonds other than the disulfide bridges and increased the redispersibility, when the stored $11 \mathrm{~S}$ globulin aggregates were kept in the $0.5 \%$ SDS solution.

Acknowledgment. We wish to thank Mr. M. Asano for his good advice in scanning electron microscopic observations.

\section{REFERENCES}

1) U. Yoshino, Y. Iwasaki, M. Okubo and T. Okayama, Nippon Shokuhin Kogyo Gakkaishi, 24, 526 (1977).

2) K. Saio and M. Arisaka, Nippon Shokuhin Kogyo Gakkaishi, 25, 451 (1978).

3) K. Saio, I. Nikkuni, Y. Ando, M. Ohtsuru, Y. Terauchi and M. Kito, Cereal Chem., 57, 77 (1980).

4) K. Saio and K. Baba, Nippon Shokuhin Kogyo Gakkaishi, 27, 343 (1980).

5) Y. Nakayama, K. Saio and M. Kito, Cereal Chem. 58, 260 (1981).

6) Y. Nakayama and M. Kito, Agric. Biol. Chem., 45, 2155 (1981).

7) S. Okamoto and K. Matsuura, Nippon Shokuhin Kogyo Gakkaishi, 21, 239 (1974).

8) T. Ohta, K. Takano, I. Nikkuni, K. Hashizume and K. Saio, Rept. Natl. Food Res. Inst., 35, 56 (1979).

9) H. Chiba, R. Sasaki, M. Yoshikawa and K. Ikura, Food and Nutrition, 34, 201 (1981).

10) Y. Miura and M. Komeyasu, Nippon Shokuhin Kogyo Gakkaishi, 28, 41 (1981).

11) Y. Miura and M. Komeyasu, Nippon Shokuhin Kogyo Gakkaishi, 29, 460 (1982).

12) Y. Miura and M. Komeyasu, Nippon Shokuhin Kogyo Gakkaishi, 29, 466 (1982). 
13) S. Honma and M. Fujimaki, Agric Biol. Chem., 46, 301 (1982).

14) Y. Hoshi, F. Yamauchi and K. Shibasaki, Agric. Biol. Chem., 46, 1513 (1982).

15) Y. Hoshi, F. Yamauchi and K. Shibasaki, Nippon Shokuhin Kogyo Gakkaishi, 29, 496 (1982).

16) Y. Hoshi, F. Yamauchi and K. Shibasaki, Agric. Biol. Chem., 46, 2803 (1982).

17) A. K. Smith and S. J. Circle, "Soybeans: Chemistry and Technology," Vol. 1, Proteins, The Avi Publishing Co., Inc., Westport, Connecticut, 1972.

18) V. H. Thanh, K. Okubo and K. Shibasaki, Plant
Physiol., 56, 19 (1975).

19) W. J. Wolf, G. E. Babcock and A.K. Smith, Arch. Biochem. Biophys., 99, 265 (1962).

20) R. T. Swank and K. D. Munkres, Anal. Biochem., 39, 462 (1971).

21) W. J. Wolf and F. L. Baker, Cereal Chem., 52, 387 (1975).

22) K. Kitamura, T. Takagi and K. Shibasaki, Agric. Biol. Chem., 40, 1837 (1976).

23) T. Yamagishi, F. Yamauchi and K. Shibasaki, Agric. Biol. Chem., 44, 1575 (1980). 